\title{
ADAPTABILITY OF NEWLY IMPROVED CREEPING BENTGRASS (Agrostis stolonifera L.) GENOTYPES IN A MEDITERRANEAN ENVIRONMENT
}

\author{
Yasar Tuncer KAVUT*, Riza AVCIOGLU, Gulcan DEMIROGLU, Hakan GEREN, Behcet KIR \\ Ege University, Faculty of Agriculture, Department of Field Crops, Izmir, TURKEY \\ *Corresponding author: tuncer.kavut@ege.edu.tr
}

Recieved: 25.11.2013

\begin{abstract}
Creeping bentgrass (Agrostis stolonifera L.), with a mild shade tolerance, is a stoloniferous cool season turf grass adaptable to temperate climatic conditions. Recently new genotypes were improved by breeders in the USA, having respectively higher heat and drought tolerance. In an attempt to evaluate the adaptability of this type of bentgrass genotypes, an experiment were established on the experimental farm located at Bornova, Ege Univ. Agric. Faculty, Izmir, Turkey during the years of 2007 and 2009. Six genotypes of bentgrass and traditional cultivar "Kromi" as control were tested for two years and turf grass color, cover, weed infestation and turf quality were assessed by a visual scoring (1-9 points). Results indicated significant variations among the genotypes in terms of the evaluated characteristics and the average adaptability of some genotypes of which some traits such as cover and turf quality were in an acceptable range. It was also suggested that distinguished genotypes such as genotype M65-6-OVN-28, M71-6-26-294 and M39-6-20 should be tested furthermore and for other agronomical characteristics.
\end{abstract}

Key Word: adaptability, creeping bent grass, mediterranean environment

\section{INTRODUCTION}

A turf provides beauty and attractiveness for human activities. The clean, cool and natural greenness of turf provides a pleasant environment in which to live and work (Demiroglu et al., 2011). However, it should be emphasized that cool season turf grass maintenance requires a detailed preference and selection of proper grass particulary in the Mediterranean environments and even in the continental parts of the Middle East countries. Diagnosing the increasing abiotic stress effects of global warming in recent years, we should also emphasize that turf culture must be directed towards the improvement of turf grasses bearing higher heat and drought stress resistance which will lower water requirements as competition for water use increases in different sectors (Beard, 1973; Martinello and D'Andrea, 2006).

Paulsen (1994) indicated that heat and drought stress, which represent the essential characteristics of the Mediterranean ecological conditions is becoming two of the major abiotic stress factors limiting the growth and development of the cool-season grasses. Under those circumstances, efficient selection of turf grasses resistant to heat and drought stress is becoming a major step to achieve a successful turf establishment (Harivandi et al., 1984). It is a fact that, appropriate use of C-3 turf grasses for implanting lawns require field evaluation of the genotypes in sites with Mediterranean climate. Previous studies in the Mediterranean areas indicated the superiority of Festuca arundinacea in many aspects (Volterrani et al., 2001), however, rough texture and relatively lower turf quality traits of this grass directed the researchers to investigate and improve other alternative grasses with high heat and drought resistance in addition to high turf quality. Newly improved Agrostis stolonifera genotypes are promising alternatives with preferable turf quality as well as acceptable heat and drought resistance in the Mediterranean environment (Turgeon, 2004)

Russi et al. (2004) highlighted that turf quality is a complex characteristics with fundamental importance in turf grass evaluation. The visual evaluation of turf quality, which is based on a combination of color, density, uniformity, disease or environmental stress, etc. usually assessed monthly or seasonally on a scale ranging from 1 to 9 are highly regarded variables in the USA and the European national tests (Morris and Sherman, 2000). Despite their limitations, turf quality, color, cover and weed infestation traits of turf remain as fundamental characteristics used by turf researchers because the process is much less time-consuming than the alternative options based on individual traits and can, therefore, be easly assessed several times a year (Russi et al., 2004).

In this study, considering the previous studies conducted in the region and resembling ecologies, newly improved genotypes of Agrostis stolonifera L. from the Oregon State Universty USA, (M65-6-OVN-382, M65-6OVN-28, M71-6-26-21, M71-6-26-294, M39-6-20, M39- 
6-20-277 and commercial cultivar Kromi) were tested for turf color, cover, weed infestation and quality traits to obtain information for their adaptability to the Mediterranean climatic conditions, to be useful in the advanced stages of the improvement and the breeding studies.

\section{MATERIALS AND METHODS}

The experiment was established in November, 2007 on the experimental farm located at Bornova $\left(38^{\circ} 27.236 \mathrm{~N}\right.$, $27^{\circ} 13.576 \mathrm{E}$ and $28 \mathrm{~m}$ above sea level with typical Mediterranean climatic conditions), Ege University Agriculture Faculty, Izmir, Turkey. Average temperature during the experimental years of 2008 and 2009 was 18.8 , $18.7^{\circ} \mathrm{C}$, respectively in accordance with the long term average $\left(17.1^{\circ} \mathrm{C}\right)$; but the precipitation $(2008: 373.4 \mathrm{~mm}$ and 2009: $1071.9 \mathrm{~mm}$ ) of the two succeeding years, was different when compared to the long term average of $596.3 \mathrm{~mm}$.

The native root zone was composed of $80.2 \%$ sand, $18.1 \%$ silt and $1.7 \%$ clay. The soil was loamy sand with $\mathrm{pH} 8.1$; total $\left(\mathrm{CaCO}_{3}\right) 2400 \mathrm{mg} \mathrm{kg}^{-1}$; total nitrogen $0.2 \mathrm{~g}$ $\mathrm{kg}^{-1}$; organic matter $2.27 \mathrm{~g} \mathrm{~kg}^{-1}$; available phosphorus 2.54 $\mathrm{mg} \mathrm{kg}^{-1}$; exchangeable potassium $150 \mathrm{mg} \mathrm{kg}^{-1}$.

The seedbed was prepared by disrupting a perennial forage grass fallow with a mouldboard ploughed $35 \mathrm{~cm}$ deep at the beginning of september-2007. Before seedbed preparation the experimental plots were equipped with a permanent water pipeline system based on rotary sprinklers. Supplemental irrigation (38 times in the first and 36 times in the second year) were applied as needed to prevent visual wilt of the turf by sprinkling during late Spring, Summer and early Autumn. Prior to seeding, nitrogen, phosphorus and potassium fertilizers were applied at $75 \mathrm{~kg} \mathrm{ha}^{-1} \mathrm{~N}, \mathrm{P}_{2} \mathrm{O}_{5}$ and $\mathrm{K}_{2} \mathrm{O}$, respectively before leveling the soil with a cultivator and harrow (Ceylan, 1994). In the first week of November, 2007 seeds of Agrostis stolonifera L. genotypes A:M65-6-OVN-382, B:M65-6-OVN-28， C:M71-6-26-21， D:M71-6-26-294, E:M39-6-20, F:M39-6-20-277 and control cultivar Kromi were sown in the plots measuring $2 \mathrm{~m} \mathrm{x} 1 \mathrm{~m}$ at the seed rate of $10 \mathrm{~g} \mathrm{~m}^{-2}$. Plots were arranged in a Randomized Complete Block Design with four replicates. Nitrogen, phosphorus and potassium fertilizer was manually applied in all entries at a rate of $10 \mathrm{~g} \mathrm{~m}^{-2}$ in five rounds (early April, May, June, July and August) in succeeding years. The plots were mown ( 21 cuts in the first and 23 cuts in the second year) at a height of $25-30 \mathrm{~mm}$, when the creeping bentgrass was $40-50 \mathrm{~mm}$ tall by using a rotary mover, recovering and discarding the clippings.
Turf grass color (1: light green, 9 dark green), cover (1: bare soil, 9: dense cover), weed infestation (1: fully infested, 9: no infestation) (resistance) and turf quality (1: very poor quality, 9: outstandig quality) were assessed by a visual score (Morris and Sherman, 2000; Anonymous, 2001). Observations were maintained on a monthly basis and summerised as seasonal averages (Spring, Summer, Autumn, Winter) in the tables.

Statistical analysis were conducted by using the TOTEMSTAT Statistical program (Acikgoz et al., 2004). The treatments means, was compared by the LSD test described by Steel and Torrie (1980).

\section{RESULTS}

Creeping Bentgrass (Agrostis stolonifera) is a stoloniferous cool season grass with a potential to adapt to high temperature climatical conditions with shade tolerance (Avcioglu, 1997) and a widely used turf grass in the golf courses. Recently, new genotypes were improved by breeders in the USA, having drought and partly heat tolerance (Turgeon, 2004). Considering the value of these type of creeping bentgrasses with specific growth habits like stolones or rhisomes in the Mediterranean environment, essential turf features of these material were tested under the Mediterranean climatic conditions, in order to characterize their valuable traits to be used in the future breeding stages.

\section{Turf color}

Conditions of the Mediterranean climate prevailing during the turf growing period in the four seasons of each experimental year and in the two years average significantly affected turf color features of all creeping bent grass genotypes tested in the study (Table 1). Analysis of variance results also displayed significant Fvalues for years, seasons and genotypes (lines) for the turf color features. It was determined that two and three factor interactions were also significant. All turf genotypes best adapted to mild and humid seasons like spring and autumn for all traits tested, whereas those scores were extremely lower during the summer and the winter seasons in both years and in average of two years. However, genotype B (6.59) and D (6.56) performed better than the others and the control cultivar Kromi a local variety commercialy grown in the area for many years. In general, color scores of all genotypes and control were limited in all seasons of both years, although the scores increased in the second year, particularly in the spring and the autumn seasons. Genotype A (4.98) and F (5.74) had also ultimately limited color scores compared to others and control variety. Genotype $\mathrm{C}$ ranked intermediate among all other turf grass alternatives. 
Table 1. Turf color of tested genotypes of bent grass (Agrostis stolonifera L.) grown at Bornova-Izmir-Turkey (a Mediterranean environment)

\begin{tabular}{|c|c|c|c|c|c|c|c|c|c|c|c|c|c|c|c|c|}
\hline \multicolumn{17}{|c|}{ Turf color } \\
\hline \multirow[b]{2}{*}{$\begin{array}{c}\text { Code } \\
\text { Letter }\end{array}$} & \multirow[b]{2}{*}{ Genotypes } & \multicolumn{5}{|c|}{2008} & \multicolumn{4}{|c|}{2009} & \multicolumn{6}{|c|}{ Mean } \\
\hline & & win & spr & sum & aut & Mean & win & spr & sum & aut & Mean & win & spr & sum & aut & Mean \\
\hline A & $\begin{array}{l}\text { M65-6-OVN-1 } \\
(382)\end{array}$ & 4.20 & 5.10 & 4.90 & 5.08 & 4.82 & 4.50 & 5.40 & 5.38 & 5.25 & 5.13 & 4.35 & 5.25 & 5.14 & 5.16 & 4.98 \\
\hline B & $\begin{array}{l}\text { M65-6-OVN-1 } \\
(28)\end{array}$ & 6.03 & 6.15 & 6.18 & 7.00 & 6.34 & 6.50 & 6.70 & 6.75 & 7.40 & 6.84 & 6.26 & 6.43 & 6.46 & 7.20 & 6.59 \\
\hline $\mathrm{C}$ & M71-6-26 (21) & 6.03 & 6.20 & 6.43 & 6.30 & 6.24 & 6.18 & 6.85 & 6.48 & 6.98 & 6.62 & 6.10 & 6.53 & 6.45 & 6.64 & 6.43 \\
\hline $\mathrm{D}$ & M71-6-26 (294) & 6.00 & 6.25 & 6.88 & 6.80 & 6.48 & 6.30 & 7.00 & 5.91 & 7.35 & 6.64 & 6.15 & 6.63 & 6.40 & 7.08 & 6.56 \\
\hline $\mathrm{E}$ & M39-6-20 (30) & 4.73 & 5.58 & 5.40 & 6.63 & 5.58 & 5.33 & 7.45 & 7.40 & 5.45 & 6.41 & 5.03 & 6.51 & 6.40 & 6.04 & 5.99 \\
\hline $\mathrm{F}$ & M39-6-20 (277) & 4.79 & 6.10 & 5.30 & 6.45 & 5.66 & 5.08 & 6.03 & 5.05 & 7.13 & 5.82 & 4.93 & 6.06 & 5.18 & 6.79 & 5.74 \\
\hline G & Kromi & 5.35 & 5.58 & 5.70 & 6.75 & 5.84 & 5.90 & 6.28 & 6.18 & 7.13 & 6.37 & 5.63 & 5.93 & 5.94 & 6.94 & 6.11 \\
\hline Mean & & 5.30 & 5.85 & 5.83 & 6.43 & 5.85 & 5.68 & 6.53 & 6.16 & 6.67 & 6.26 & 5.49 & 6.19 & 5.99 & 6.55 & 6.06 \\
\hline \multirow{2}{*}{$\begin{array}{l}\text { LSD } 005 \\
\text { values }\end{array}$} & \multicolumn{3}{|c|}{ Genotype mean over 2 years: 0.10} & \multirow{2}{*}{\multicolumn{5}{|c|}{$\begin{array}{l}\text { Season mean over } 2 \text { years }: 0.08 \\
\text { Genotype mean for each year: } 0.17\end{array}$}} & \multirow{2}{*}{\multicolumn{4}{|c|}{$\begin{array}{ll}\text { Season mean for each year } & : 0.13 \\
\text { Genotype mean over each season: } 0.20\end{array}$}} & \multirow{2}{*}{\multicolumn{4}{|c|}{$\begin{array}{l}\text { Genotype mean over season } \\
\text { and year: } 0.35\end{array}$}} \\
\hline & Mean of 2008- & & $: 0.07$ & & & & & & & & & & & & & \\
\hline
\end{tabular}

\section{Turf cover}

As an indication of vigorous and rapid growth based on the higher rate of metabolic activity and development in addition to higher rate of tillering, the cover trait is a favourable characteristic to evaluate and select the potential turf grass alternatives (Martinello, 2005). The turf cover evaluation scores of turf grass genotypes tested in the experiment were also displayed in the Table 2. Statistical analysis indicated that the F-values for year, genotype, season and year $\mathrm{x}$ season interaction effects were significant, while for the year $\mathrm{x}$ genotype and year $\mathrm{x}$ genotype $\mathrm{x}$ season interactions were not significant.

Cover scores of creeping bentgrass genotype B, D, E and control cultivar were higher than those of others in the first year and and same material maintained their higher performances during the second year. It was also noticed that all genotypes including control variety performed satisfactorily in the second year of the experiment and this general high performances of all genotypes were also reflected in average of two years (Table II). However, the inconsistent cover scores of tested turf grasses differed in various seasons. All genotypes had promising cover scores in the spring and the autumn periods, alltough the scores were again inconsistent and quite limited in the summer and the winter. These results were also similar to succeeding scores in the second year of the experiment. The genotypes E, D, B and the control cultivar $(7.89,7.86$, 7.84 and 7.85 , respectively) had higher scores than those of the others in the second year again and overall cover performances of genotypes reflected similar tendency in the average of two years.

Table 2. Turf cover of tested genotypes of bent grass (Agrostis stolonifera L.) grown at Bornova-Izmir-Turkey (a Mediterranean environment)

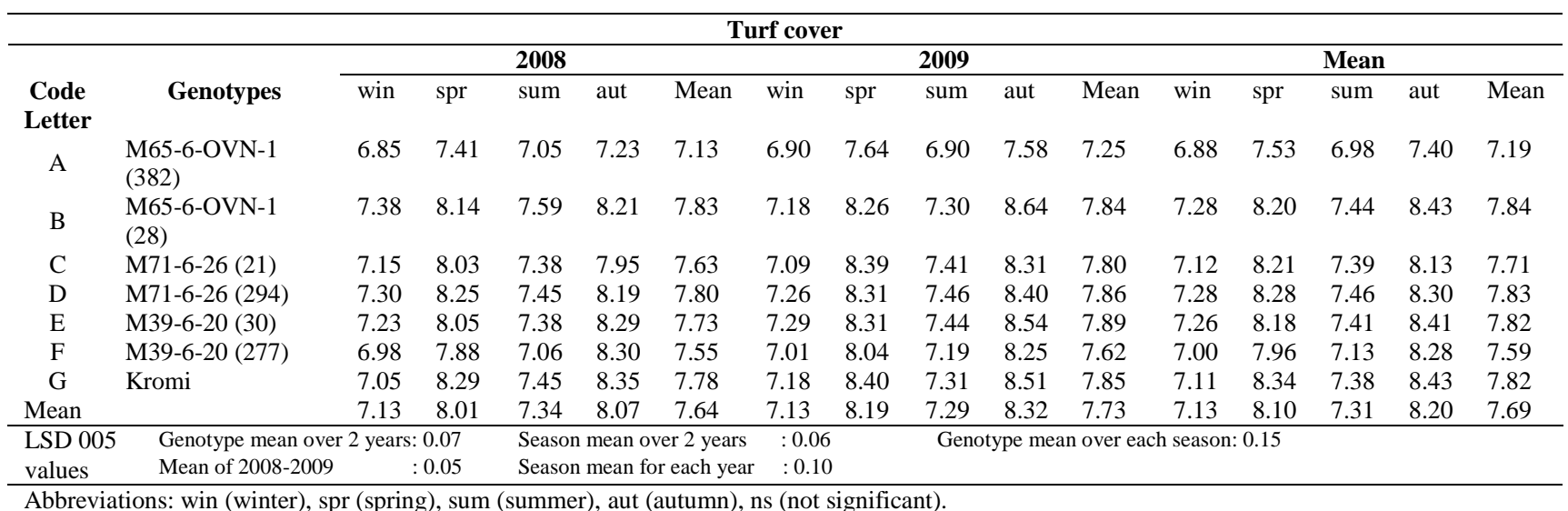




\section{Weed infestation}

The analysis of variance for weed infestation (resistance) scores of turf grass genotypes tested in the experiment revealed the significant main effects of genotypes, seasons, years and genotype $\mathrm{x}$ season and year $x$ genotype interaction, whereas other two and three factor interactions were not significant. The genotypes B, D, A and $\mathrm{E}$ had higher average scores $(6.19,5.62,5.50$ and 5.49 , respectively) compared to others in the first year, while control cultivar (5.07) and the genotype F (5.09) and the C (5.28) had lowest scores (Table 3). The weed infestation scores of the same turf grass alternatives with high scores in the first year were also similar to the succeeding year.

The average of two years of higher weed invasion scores (lower weed infestation) of these turf grass genotypes were another indication of the superiority over the other grass genotypes and higher resistance to weed infestation. The genotype $\mathrm{x}$ year interaction was not significant and on the contrary, the genotype $\mathrm{x}$ season interaction was significant and almost all turf grasses tested had better weed infestation scores in the spring and autumn. The average weed infestation scores in the spring (6.11) and the autumn (6.67) were higher than the scores in the winter (4.43) and the summer (4.65) in the first year. Genotype A (6.13) and B (6.83) possessed higher scores in the spring, while the genotypes B, D and E performed better than the others in the autumn in the first year and, similar results were obtained in the second year and in average of two years, the genotypes A, B and D being the most successful turf grass alternative for lower weed infestation.

Table 3. Weed infestation of tested genotypes of bent grass (Agrostis stolonifera L.) grown at Bornova-Izmir-Turkey (a Mediterranean environment)

\begin{tabular}{|c|c|c|c|c|c|c|c|c|c|c|c|c|c|c|c|c|}
\hline \multicolumn{17}{|c|}{ Weed infestation } \\
\hline \multirow[b]{2}{*}{$\begin{array}{l}\text { Code } \\
\text { Letter }\end{array}$} & \multirow[b]{2}{*}{ Genotypes } & \multicolumn{5}{|c|}{2008} & \multicolumn{5}{|c|}{2009} & \multicolumn{5}{|c|}{ Mean } \\
\hline & & win & spr & sum & aut & Mean & win & spr & sum & aut & Mean & win & spr & sum & aut & Mean \\
\hline A & $\begin{array}{l}\text { M65-6-OVN-1 } \\
(382)\end{array}$ & 4.41 & 6.13 & 4.85 & 6.63 & 5.50 & 5.21 & 7.08 & 5.38 & 7.66 & 6.33 & 4.81 & 6.60 & 5.11 & 7.14 & 5.92 \\
\hline B & $\begin{array}{l}\text { M65-6-OVN-1 } \\
\text { (28) }\end{array}$ & 5.15 & 6.83 & 5.55 & 7.23 & 6.19 & 5.16 & 6.70 & 5.43 & 7.69 & 6.24 & 5.16 & 6.76 & 5.49 & 7.46 & 6.22 \\
\hline $\mathrm{C}$ & M71-6-26 (21) & 4.05 & 6.06 & 4.78 & 6.25 & 5.28 & 4.06 & 6.25 & 4.59 & 6.93 & 5.46 & 4.06 & 6.16 & 4.68 & 6.59 & 5.37 \\
\hline $\mathrm{D}$ & M71-6-26 (294) & 4.80 & 6.09 & 4.59 & 7.01 & 5.62 & 5.15 & 6.66 & 5.09 & 7.35 & 6.06 & 4.98 & 6.38 & 4.84 & 7.18 & 5.85 \\
\hline $\mathrm{E}$ & M39-6-20 (30) & 4.50 & 5.94 & 4.51 & 7.01 & 5.49 & 4.90 & 6.30 & 4.55 & 7.16 & 5.73 & 4.70 & 6.12 & 4.53 & 7.09 & 5.61 \\
\hline $\mathrm{F}$ & M39-6-20 (277) & 4.04 & 5.88 & 4.15 & 6.31 & 5.09 & 5.01 & 6.23 & 4.74 & 7.01 & 5.75 & 4.53 & 6.05 & 4.45 & 6.66 & 5.42 \\
\hline G & Kromi & 4.03 & 5.89 & 4.14 & 6.23 & 5.07 & 4.60 & 6.23 & 4.64 & 7.04 & 5.63 & 4.31 & 6.06 & 4.39 & 6.63 & 5.35 \\
\hline Mean & & 4.43 & 6.11 & 4.65 & 6.67 & 5.46 & 4.87 & 6.49 & 4.91 & 7.26 & 5.89 & 4.65 & 6.30 & 4.78 & 6.97 & 5.68 \\
\hline $\begin{array}{l}\text { LSD } 005 \\
\text { values }\end{array}$ & $\begin{array}{l}\text { Genotype mean over } \\
\text { Mean of 2008-2009 }\end{array}$ & 2 years & $\begin{array}{l}0.11 \\
0.07\end{array}$ & $\begin{array}{l}\text { Seaso } \\
\text { Genot }\end{array}$ & $\begin{array}{l}\text { mean o } \\
\text { e mean }\end{array}$ & $\begin{array}{l}\text { r } 2 \text { years } \\
\text { or each y }\end{array}$ & $\begin{array}{r}: 0.08 \\
\text { ar: } 0.19\end{array}$ & & Genoty & mean & er eacl & ason: ( & & & & \\
\hline
\end{tabular}

Abbreviations: win (winter), spr (spring), sum (summer), aut (autumn), ns (not significant).

\section{Turf quality}

Visual turf grass quality estimates were based on primarily on a composite of three components; turf color, density and uniformity of appearance (1: poorest, 9: highest quality). The mean turf quality scores of tested turf grass alternatives in the experiment in each season and year of evaluation were displayed in Table 4. Analysis of variance of the quality scores had significant F-values indicating the significant main effects of season, turf grass genotypes and two and three factor interactions, except year and the year $\mathrm{x}$ season interaction.

Turf quality scores of the genotypes D, B, C and the control cultivar $(6.58,6.49,6.38$ and 6.16 , respectively) were significantly higher than those of others in the first year. The superiority of those turf grasses in terms of quality were also consistent in the second year. Therefore, average over two years for turf quality scores confirmed the higher adaptability levels of the turf genotypes B, C and $\mathrm{D}$. The turf grass material of the experiment were highly affected by the seasons. In general, the mean quality scores of spring and autumn were ultimately higher than those of the winter and the summer in both years. Genotype B, C and D had the highest quality scores in both spring and autumn in the first year and maintained their higher performances also in the second year.

The turf grass genotypes A, E and F (5.51, 5.54 and 5.80 , respectively) had lower quality means than the others and the control cultivar almost in all seasons and the experimental years whereas the control cultivar Kromi displayed inconsistent quality scores throughout the experimental years in different seasons. 
Table 4. Turf quality of tested genotypes of bent grass (Agrostis stolonifera L.) grown at Bornova-Izmir-Turkey (a Mediterranean environment)

\begin{tabular}{|c|c|c|c|c|c|c|c|c|c|c|c|c|c|c|c|c|}
\hline \multicolumn{17}{|c|}{ Turf quality } \\
\hline \multirow[b]{2}{*}{$\begin{array}{l}\text { Code } \\
\text { Letter }\end{array}$} & \multirow[b]{2}{*}{ Genotypes } & \multicolumn{5}{|c|}{2008} & \multicolumn{5}{|c|}{2009} & \multicolumn{5}{|c|}{ Mean } \\
\hline & & win & $\mathrm{spr}$ & sum & aut & Mean & win & spr & sum & aut & Mean & win & spr & sum & aut & Mean \\
\hline A & $\begin{array}{l}\text { M65-6-OVN-1 } \\
\text { (382) }\end{array}$ & 3.33 & 6.48 & 5.00 & 7.00 & 5.45 & 3.18 & 6.70 & 5.30 & 7.10 & 5.57 & 3.25 & 6.59 & 5.15 & 7.05 & 5.51 \\
\hline B & $\begin{array}{l}\text { M65-6-OVN-1 } \\
\text { (28) }\end{array}$ & 4.78 & 7.68 & 5.75 & 7.78 & 6.49 & 4.73 & 7.64 & 6.49 & 8.18 & 6.76 & 4.75 & 7.66 & 6.12 & 7.98 & 6.63 \\
\hline $\mathrm{C}$ & M71-6-26 (21) & 4.65 & 7.53 & 5.78 & 7.55 & 6.38 & 4.78 & 7.58 & 6.08 & 7.75 & 6.54 & 4.71 & 7.55 & 5.93 & 7.65 & 6.46 \\
\hline $\mathrm{D}$ & M71-6-26 (294) & 4.78 & 7.48 & 6.18 & 7.90 & 6.58 & 4.60 & 7.50 & 6.40 & 8.00 & 6.63 & 4.69 & 7.49 & 6.29 & 7.95 & 6.60 \\
\hline $\mathrm{E}$ & M39-6-20 (30) & 3.78 & 7.08 & 5.58 & 7.48 & 5.98 & 4.10 & 6.10 & 4.10 & 6.10 & 5.10 & 3.94 & 6.59 & 4.84 & 6.79 & 5.54 \\
\hline $\mathrm{F}$ & M39-6-20 (277) & 3.90 & 7.10 & 5.35 & 7.15 & 5.88 & 4.50 & 6.70 & 4.95 & 6.73 & 5.72 & 4.20 & 6.90 & 5.15 & 6.94 & 5.80 \\
\hline $\mathrm{G}$ & Kromi & 4.63 & 7.58 & 6.08 & 6.38 & 6.16 & 4.65 & 7.70 & 6.40 & 6.73 & 6.37 & 4.64 & 7.64 & 6.24 & 6.55 & 6.27 \\
\hline Mean & & 4.26 & 7.27 & 5.67 & 7.32 & 6.13 & 4.36 & 7.13 & 5.67 & 7.23 & 6.10 & 4.31 & 7.20 & 5.67 & 7.27 & 6.12 \\
\hline $\begin{array}{l}\text { LSD } 005 \\
\text { values }\end{array}$ & $\begin{array}{l}\text { Genotype mean } \\
\text { Season mean ove }\end{array}$ & $\begin{array}{l}2 \text { year } \\
\text { years }\end{array}$ & $\begin{array}{l}0.12 \\
0.09\end{array}$ & $\begin{array}{l}\text { Genot } \\
\text { Genot }\end{array}$ & $\begin{array}{l}\text { e mean } \\
\text { e mean }\end{array}$ & $\begin{array}{l}\text { each y } \\
\text { er each }\end{array}$ & $\begin{array}{l}\text { ar: } 0.21 \\
\text { eason: }\end{array}$ & & Gen & ype me & over: & on and & ear: 0.4 & & & \\
\hline
\end{tabular}

\section{DISCUSSION}

The tested turfgrass genotypes performed differently under the Mediterranean environmental conditions prevailing in the experimental area. The great variation occurring among the genotypes in terms of color, cover, weed infestation and quality scores proved the better adaptability of some new genotypes to the weather conditions of the spring and the autumn seasons which heat and drought stress did not exist. Genoytpe B, C and D were the most promising turf grass material, performing generaly much better than the control cultivar Kromi. In contrast, all the turf grass genotypes and the control variety had reduced adaptability during the summer and the winter seasons in both years might be attributed to the heat and drought stress in the summer and respectively cold stress in the winter. These stress factors arising from weather conditions of the summer and winter seasons under the mediterranean environment have generaly restrictive effect on plant growth and development particulary for some cool season grasses (Russi et al., 2004; Sheng et al., 2005; Demiroglu et al., 2010).

Turf grass color scores may also help to define the most appropriate alternative to select, particularly with regard to the seasons in which turf color is considered of special significance (Morris and Sherman, 2000; Salman et al., 2011). The higher turf color scores of genotype B, D and $\mathrm{E}$ during the summer season which is the least favourable period of the year for growth of many cool season turf grasses in the mediterranean environment, were mainly due to comparatively greater color retention, heat and drought tolerance of above mentioned experimental grass material (Russi et al., 2004). Among the cover scores of all creeping bentgrass genotypes tested in the experiment, genotypes B, C, E and the control cultivar had highest scores in various seasons of the experimental years and over two years of average. The results of color and cover scores almost in all seasons and also in the summer revealed the promising performances of genotypes B, D, E and the control variety which mirrored their potential adaptability to mediterranean ecologies (Anonymous, 2009). Our results of color and cover performances were not in agreement with the information given by Ackkgoz (1994) and Avcioglu (1997), but in accordance with the comments and suggestions of Harivandi et al. (1984). Genoytpe A, F and particularly $\mathrm{C}$ in some seasons did not seem adaptable to these conditions during the experimental period, however they maintained their existence in the stands, although the color and cover scores were very limited. These results may be due to the poorer level of drought and heat resistance of these genotypes than that of by others under the mediterranean environmental conditions (Beard, 1973; Avcioglu, 1997).

Weeds are among the major problems of turf stands and can reduce the growth of turf grass, being a host to the pests, competing with turf grass for water, light, space, nutrient and establishing more readily in thin and weak turf stands, instead of a vigorous and healthy turf (Gaussoin and Martin, 1994; Roberta et al., 2005). Since, the presence of weeds in a turf grass community disrupts the uniformity and quality due to the variability in leaf width, color and growth habit, competitive ability and aggressive growth behaviour of turf grass is the main factor to establish and maintain a satisfactory stand (Salman et al., 2011). Weed invasion scores of turf genotypes tested in the experiment differed ultimately in both years including seasons. Genotypes B and D were turf grass cultivars resistant to weed infestation, mirroring their abilities to compete with weeds and possesing higher scores than other genotypes and the control cultivar respectively. Although all genotypes maintained their existence throughout the experimental period, weed infestation scores were not high enough even for the favourable genotypes, most probably, due to the acknowledged susceptibility of cool season grasses like bent grasses to heat stress encountered by crops mainly in the summer season in the mediterranean environment (Beard, 1973). Studying under cool season climatic conditions Yllmaz and Avcioglu (2000) and Zorer et al. (2009) also stated that cool season grasses performed very well under the cool climatical conditions of Tokat and Van provinces located in the cooler zones of Turkey.

The turf quality is a widely used criterion to define the overall performances of turf stands (Kir et al., 2010). The 
results of the turf quality scores obtained in the experiment also indicated that genotype $\mathrm{B}, \mathrm{D}, \mathrm{F}$ and to some extent genotype $\mathrm{C}$ were more promising turf grasses as compared to the others and the control cultivar. Altough the overall scores of both groups of grasses in different seasons of two years were always limited and far from to be excellent, significantly higher scores of genotypes B, D and C than the others and sustainability of this respectively high performances throughout the years confirmed the acceptable adaptability level of these genotypes to the mediterranean environment. In a study on cool season turf grass adaptability under the SubMediterranean conditions of Turkey, Oral and Acikgoz (1998) indicated the resembling behaviour of some cool season turf grasses.

\section{CONCLUSION}

The two years results of our study were in aggrement with the reports of the researchers indicating the adaptability of some bent grass cultivars to respectively shady conditions of the mediterranean environment and temperate regions. It could be suggested that, genotypes $\mathrm{B}, \mathrm{D}$ and $\mathrm{E}$ were the promising turf grass material to be tested furthermore to determine their related agronomical and genetical characteristics.

\section{LITERATURE CITED}

Anonymous. 2001. Technical Instruction for Agronomical Evaluation Experiments. Turf grass, Ministry of Agricultural and Rural Affairs, TTSM, Ankara-Turkey (in Turkısh).

Anonymous. 2009. Turf Adaptations and Tolerances. The UC Guide to Healtly Lawns, University of California Agriculture and Natural Resources, http://ipm.ucdavis.edu/TOOLS/TURF/TURFSPECIES/creep bent.html (Accessed December 10, 2013).

Acikgoz, E. 1994. Turf Areas, Techniques of Establishment and Maintenance. Environmental landscape, Publish, Bursa (in Turkısh).

Acikgoz, N., E. Ilker and A. Gokcol. 2004. Assessment of Biological Research on the Computer. EU TOTEM, İzmir (in Turk1sh).

Avcioglu, R. 1997. Turf Technique (Turf Establishment \& Management). Ege University Press, Izmir, Turkey (in Turk1sh).

Beard, J.B. 1973. Turf Grass: Science and Culture. Prentice-Hall Inc., Englewood Cliffs, NJ, USA.

Demiroğlu, G., B. Kir, R. Avcioglu and H. Geren. 2010. An Investigation on the Yield and Quality Performances of Some Rotation Pasture Mixtures under Different Harvest Treatments. African J. Biotechnol., 9: 7877-7884.

Demiroglu, G., R. Avcioglu, B. Kir and A. Salman. 2011. Investigations on Texture Weed Invasion and Density Features of Some Cool Season Turf Grass Cultivars in Mediterranean Environment. International Journal of Agriculture \& Biology, 13: 461-468.

Gaussoin, R. and A. Martin. 1994. Turf grass Weed Prevention and Management. http://ianrpubs.unl.edu/Weeds/g1045.htm (Accessed November 20, 2013).

Harivandi, M.A., W. Davis, V.A. Gibeault, M. Henry, J.V. Dam and L. Wu. 1984. Selecting The Best Turfgrass. California Turfgrass Culture, 34: 17-24.
Ceylan, A. 1994. Principles of Agronomy. Ege Uni. Faculty of Agri. Publ. 491(in Turkısh).

Kir, B., G. Demiroglu, R. Avcioglu and H. Geren. 2010. Effect of Sowing Techniques and Harvesting Treatments on the Performances of Some Rotation Pasture Mixtures. African J. Biotechnol., 9: 6666-6669.

Martinello, P. and E. D'Andrea. 2006. Cool-season Turf grass Species Adaptability in Mediterranean Environments and Quality Traits of Varieties. European J. Agron., 25: 234242.

Morris, K.N. and R.C. Sherman. 2000. The National Turfgrass Evaluation Program: Assessing New and Improved Varieties. Diversity, 16: 19-22.

Martinello, P. 2005. Variability of Turf Quality and Phytocoenoses in Areas of Play in Football Grounds in Mediterranean Environments. Agric. Med., 135: 209-220.

Oral, N. and E. Acikgoz. 1998. The Investigations on the Seed Mixtures, Seeding Rate, N-fertilization in the Turfs Established in Bursa Region. Ph. D Thesis, Uludağ University Department of Field Crops, Bursa, Turkey (in Turkish).

Paulsen, G.M. 1994. High Temperature Responses of Crop Plants. In: Boote, K.J., J.M. Bennett, T.R. Sinclair and G.M. Paulsen (eds.), Physiology and Determination of Crop Yield, pp: 365-389. ASA, CSSA and SSSA, Madison, WI.

Roberta, M., C.Z. Maria, W.A. David and Z. Giuseppe. 2005. Weed Turf: A Predictive Model to Aid Control of Annual Summer Weeds in Turf. Weed Sci., 53: 193-201.

Russi, L., P. Annicchiarico, P. Martiniello, C. Tomasoni, E. Piano and F. Veronesi. 2004. Turf Quality and Reliability in Varieties of Four Turfgrass Species in Contrasting Italian Environments. Grass Forage Sci.,59: 233-239.

Salman, A., R. Avcioglu, H. Oztarhan, A.C. Cevheri and H. Okkaoglu. 2011. Performances of different cool season turf grasses and some mixtures under mediterranean environmental condition. Int. J. Agric. Biol., 13: 529-534.

Steel, R. G. D. and J. H. Torrie, 1980. Principles and Procedures of Statistics, Second Edition, New York: McGraw-Hill.

Turgeon, A.J. 2004. Creeping Bentgrass. Penn State University Park PA, http://turfgrass.cas.psu.edu/education/turgeon/Modules/03_T urfgrassSpecies/Characterization/bentgrass_creeping/MainSe t.html (Accessed December 10, 2013).

Sheng, X., L. Jianlong, Z. Xinquan, W. Hong and C. Langjun. 2005. Effects of Heat Acclimation Pretreatment on Changes of Membrane Lipid Peroxidation, Antioxidant Metabolites and Ultrastructure of Chloroplasts in Two Cool-Season Turfgrass Species under Heat Stress. Environ. Expt. Bot., 56: 274-285.

Volterrani, M., S. Miele, S. Magni, M. Gaetani and G. Pardini. 2001. Bermuda-grass and seashore paspalum winter overseeded with seven cool-season turf grasses. Int. Turf grass Soc. Res. J., 9: 957-961.

Yilmaz, M. and R. Avcioglu, 2000. Investigation on seed yield and turf properties of some grasses grown for turfgrass and erosion control purposes in Tokat, Turkey. Ege University Faculty of Agriculture, Dept. of Field Crops, (Unpublished PhD Thesis), p. 220 (in Turkish).

Zorer, S., N. Andic and İ.H. Yilmaz. 2009. Determination of Proper Species Mixtures for Established Turf grass Field in Van Region. YYU J. Agric. Sci., 19: 91-101. 